\title{
Organisational Change in Greece: Exploring Bottlenecks in Public Sector's Hospital Management
}

\author{
Georgia Oikonomopoulou \\ Panteion University of Social and Political Sciences, Athens, Greece \\ Email: goikonomopoulou@eemyy.gr
}

How to cite this paper: Oikonomopoulou, G. (2021). Organisational Change in Greece: Exploring Bottlenecks in Public Sector's Hospital Management. Open Journal of Social Sciences, 9, 43-53.

https://doi.org/10.4236/jss.2021.94005

Received: February 28, 2021

Accepted: April 9, 2021

Published: April 12, 2021

Copyright ( 2021 by author(s) and Scientific Research Publishing Inc. This work is licensed under the Creative Commons Attribution International License (CC BY 4.0).

http://creativecommons.org/licenses/by/4.0/

\section{(c) (i) Open Access}

\begin{abstract}
During the last twenty years, Greek governments have been announcing, using a plethora of synonyms, such as "modernization, upgrade, reform, transformation", changes in the public health sector. However, the pathogenic bureaucratic model still exists in public hospitals as well, as shown in the relevant literature, albeit the lack of research regarding hospital managers and the need for organisational change. This study focuses through theoretical triangulation on lean management model advantages and explores via empirical research on the bottlenecks in hospital's management social mission. By shedding light on managers profile the paper sought to assess their ability to imagine-capture new organisational structures, to think lean, and guide future action for the fulfillment of human needs and values in healthcare delivery in the country.
\end{abstract}

\section{Keywords}

Organisational Change, Public Hospitals, Management, Lean System

\section{Introduction}

Despite any contemporary effort that took place after Greece became a member of the European Union (E.U., 1981), public administration remained "quasiWeberian", hierarchical and centralized, under the command of each contextual political party (Sotiropoulos, 1995; Ladi, 2014; Tsarouchas, 2018). The ramifications of bureaucratic hierarchy, from the Weberian perspective of founding an "interpretive" science, "that in construing and understanding social action seeks causal explanation of the course and effects of such action", until the nowadays powerful research interest indicates that the question abides alive (Weber, 1978: 
p. 4; Weber, 2019: p. 78; Kroezen, van Dijk, Groenewegen, \& Francke, 2013; Hindhede \& Andersen, 2019).

One of the sectors, whose reform was imperatively required, during the economic crisis, and within the frame of public administration modernization ever since we entered the Memorandum period (2010), was that of public health. Nevertheless, this change was almost entirely focused on economy with horizontal downscales in public expenditure, which when it comes to the operation of the hospitals led to even greater negative consequences (Economou, 2010; Kentikelenis et al., 2014; Simou \& Koutsogeorgou, 2014; Economou et al., 2015). The essential and actual organisational change, whose aim was supposed to be the improvement of hospital administration, was never ventured within the ten years of the alleged reform, with the "Hospitals' Organisation Uniform Framework" of Presidential Decree No. 87 (Government Gazette A/32/27.3.1986) maintaining its stagnant hierarchy structure and departmentation for more than thirty years. Given that, we can easily assume that the institutional resilience (Hall \& Taylor, 1996) turned out to be mightier than external events and developments.

The introduction of the institution of hospital manager and Regional Structure of Health Care Services, by the enactment of Law 2889/2001 (Alexiadis, 2004; Aletras, Kontodimopoulos, Zagouldoudis, \& Niakas, 2007; Economou, 2010), is the only attempt to reorganize the healthcare system over the last twenty years. The establishment of Health Region Authorities was a step towards the decentralization of the system, yet it was not reflected in the agenda of the Bill, and four years later, after the change in government, the previous legislation replaced by the enactment of Law 3329/2005. However, criticism remains the same, as the adherence to the "vertical deconcentration" structures (Economou, 2010) inflates both the administrative hierarchy and bureaucracy.

Hospitals, as socially structured and orientated organisations, are obliged to respond to the expectations and the content people accredit them. The organisation theory, through its approaches to organisational analysis and prescriptions for practice, is a solid base of the ideas regarding the reflection of social changes and the study of actions by the active members. Besides, according to Parsons (1951: pp. 72, 74), sociological analysis must focus on processes (“e.g., recruitment and status-change of personnel") and any institutional changes of the society operational subsystems, whose establishment is to fulfill social purposes. Even though the understanding of the factors which define how satisfactory a public healthcare system is considered by society is a grey area (Bleich, Özaltin, \& Murray, 2009), it must be stated that public healthcare services delivery doesn't seem to have met the expectations of the Greek society (Economou \& Panteli, 2019; OECD, 2019). At the same time, international literature more and more advocates a necessary change of direction towards patient-centered and flatter organisational structures, with reduction of "waste", that is to say "from a functional/divisional model to a process-oriented model” (Martin, 2016; Fiorio, 
Gorli, \& Verzillo, 2018). So, why is it that there was no attempt to implement this new organisational trend in Greek hospitals, so as the public healthcare system can respond to the needs of modern society? Apparently, any contextual Greek government considered the cost of adhering to the same obsolete conditions much lower than that of the corresponding organisational change; and what if Hall (1993) rightly said that, the problem, as per usual, is not located in the ideas of state bureaucracy powers, but to the dominant vested interests?

This paper focus on the micro-level of Greek public hospitals administration, and within a bottom-up approach we investigate whether managers, as directly involved and surcharged with the effective management of healthcare organisations, could propose the flattening of hierarchy (lean system), aiming at the rationalism and modernization of the organisation, to the competent decision centers. In so doing we engage on a literature review, which points out that worldwide "... lean thinking in health settings is still in its infancy" and the silo-mentality remains unabated (Akmal, Greatbanks, \& Foote, 2020). When it comes to Greece, although much has been discussed about how country manage the core public administration misalignment between introduced health policies and hospital effectiveness, these studies have largely missed a focus on managers' skills and competences. The challenge now is to improve on the capability of healthcare organisations' change, and gain information and knowledge about bottlenecks, hence providing alternatives to be utilized by the Greek government, health ministry, and hospital managers.

\section{Study Methods}

The methodological approach of this study was the "theoretical triangulation", as well as an empirical qualitative research. First step was to use literature review of the last twenty years regarding critical analyses on hospital managers competencies, healthcare and public management reforms in Greece and on healthcare lean management as a theoretical framework; secondly, we examined the profile of current (January 2021) Greek hospital managers, through their designation's published data in the Government Gazette. Finally, all data were discussed through the theoretical lens of organisational theory.

The literature research was contacted on December 2020 with framework period articles published between 2001-2020. Key words used were "hospital management AND (Greek OR Greece)", as well as "lean AND hospital". Onwards, the researching of published official documents was based on the technique of content analysis, which is commonly accepted as effective and established methodology in these types of qualitative approaches (Atkinson, 2017: p. 84; Wang, 2020). Specifically, the researching involved the collection of a large number of clippings from the Government Gazette with an archive up to 480 cuttings through which the major information on the profile of all Greek hospital managers was derived. A further research on the internet was included in our investigation in order to elaborate on other profile details for managers. 


\section{Theoretical Framework-Setting the "Lean" Scene}

Joseph Juran was the first to introduce transmittal of the expertise from industry to health industry and claimed that despite the fact that “... the health industry is different..., the decisive factors in what works and what does not are the managerial processes, which are alike for all industries" (Manos, Sattler, \& Alukal, 2006). Thayer (1981: p. A6, 58) speaks about the upcoming "end to hierarchy", which is "unnatural, a cultural behavior pattern we are reluctantly learning", therefore people will replace it with consensual systems. As a more operational, yet still hierarchical, he considers the Japanese organisational model (Thayer, 1981: p. 88).

James Womack, Dan Jones and John Krafick "coined the term Lean Production in 1989" (Dennis, 2015: p. 15) for the characteristics of the Japanese model (Toyotism taken from the founder industry, or Ohnism from the chief engineer of Toyota T. Ohno). The process organisation and the reconsideration of bureaucratic size, as well as hierarchical pyramid towards the Japanese model, did not completely abolish Taylor's administrative way, it focused though on the efficiency, the automation through Information and Communications Technology (ICT), the quality of the work produced, instead of the authority, but also the flexibility and innovation and not in exercising control (Lytras, 2016: pp. 38-39). The proposition of the introduction of lean management in hospital organisation aim at the enforcement of group work, the elimination of organisational "waste" and unnecessary processes that increase operating costs and remove the focus of attention on people and their needs for health care (Mintzberg, 1997; Kollberg, Dahlgaard, \& Brehmer, 2007; Lytras, 2016: p. 41; Hassanain, 2017; Andreasson, Ljungar, Ahlstrom, Hermansson, \& Dellve, 2018; Akmal, Greatbanks, \& Foote, 2020).

Nowadays the afore mentioned propositions require more intense attention, since our experience from CoViD-19 pandemic, demonstrated globally that the current organisation of public health sector poses obstacles for the management and must be reorganized with the application of horizontal procedures which should overcome the slow bureaucratic rhythms and the conventional hierarchical system structure (Whitwell, Maynard, Barry, Cowling, \& Taraet, 2020). An important factor towards success, by implementing lean management or other organisational changes, is the existence of efficient and competent managers who promote collective work (Kotter, 1996; Diefenbach, 2013; Lytras, 2016: p. 40) while at the same time, we must bear in mind that professionally defined strategies, "resting upon clearly defined laws, rules, and principles, as a foundation" and under "complete written instructions" (Taylor, 2003: pp. 119, 138), forcefully segment the labor, and in a repulsive way towards its cooperative notion.

Nevertheless, Dr. W. Edwards Deming, best known for his role as the architect of Japan's post-World War II industrial transformation, with his moto "If Japan Can, Why Can't We?" (NBC, 1980), has paved the way.

\section{Research Findings}

The search of the literature for articles published in the period 2001-2020 using 
the terms "hospital management AND (Greek OR Greece)", returned 103 results on JSTOR and 23 on SCOPUS; however, no study had investigated the need of organisational change. Moreover, a new search with terms "lean AND hospital" (period 2001-2020) on SCOPUS returned 2.723 results, whereas the searching of "lean management" term within the results returned 1.862 articles and the searching of "Greece OR Greek" within those latest results returned $\varnothing$ articles.

\subsection{Greece: Evidence before This Study}

The inefficiency of Greek public hospitals (Aletras, Kontodimopoulos, Zagouldoudis, \& Niakas, 2007; Kounetas \& Papathanassopoulos, 2013; Niakas, 2013) constitutes an all-time national pattern, which since 2010, under the supervision of the International Monetary Fund, the European Commission, and the European Central Bank supervising committee ("Troika"), has established an international stereotype as well. The question posed is whether foreign interventions, apart from the austere fiscal adjustment, improved this convention.

As mentioned before, but also according to studies, the enactment of Law 2889/2001 did not achieve the decentralization of the decision making. On the contrary, bureaucracy was enlarged and the entire administration of healthcare system, continued its dependence on the exceedingly centralized Health Ministry. Moreover, the technical and scale hospital efficiency receded (Aletras, Kontodimopoulos, Zagouldoudis, \& Niakas, 2007; Katharaki, 2008), a fact which should not surprise us, since pre-existing pathogens, such as poor management of resources, high out-of-pocket expenditures, the informal payments, the very limited proportion of nursing staff etc. (Souliotis, Golna, Tountas, Siskou, Kaitelidou, \& Liaropoulos, 2016) cannot be addressed with an increase in the management levels but with properly designed operational organisational changes.

The absence of quality management systems and limited use of ICT in Greek public hospitals have been officially demonstrated also in valid studies. Another thing that is also documented, is the fear for new bureaucratic procedures that could be entrained by the systems' modernization, something which is assumingly connected to the quality of the pre-existing ones, as the employees seem to comprehend the ICT use benefits (Dinas, Vavoulidis, Pratilas, Basonidis, Liberis, Zepiridis, et al., 2019; Natsis, Chrysanthopoulos, \& Stamouli, 2020).

Greece, and Italy, seem to be attached to the traditional structure of Taylorism, with Germany, Sweden, Belgium, Spain and Portugal following suit but to a lesser extent (Lorenz \& Valeyre, 2004). In the "scientific management" model, the "one best method" as the theory's founder Taylor (1919: p. 25) claimed, the department fragmentation possesses a high place in the bureaucracy of an organisation and the vertical communication is enhanced (Lytras, 2016: p. 30). In the Taylor's model, managers are blinkered by their focus on their target and as a result, they lose all connection with the human-aimed product. In other words, the connection of the operational target with the social mission and the notion of "mission as an organisational goal" (Mintzberg, 1983: pp. 282-283) are eradicated.

To supplement our academic literature search on sector governance's bottle- 
necks, we try to assess the ability of current Greek hospital managers to imagine new organizational structures, to think lean, and guide future action.

\subsection{Greek Public Hospitals. Who is Leading?}

The selection of public hospital managers is finalized, after the proposition of a committee dictated by the contextual Health Minister, who in turn, publishes the corresponding appointment/designation. This decision is published in the Government Gazette and includes the candidates' diplomas, whereas the list of all candidates and their grades from the selection committee is never published.

We gathered and depicted the managers' and deputy managers data (Table 1),

Table 1. Academic title of Greek public hospital managers and deputy managers.

\begin{tabular}{|c|c|}
\hline \multirow{2}{*}{ Number } & Hospital Managers and Deputy Managers \\
\hline & Diploma \\
\hline 1 & Humanities and Social Sciences \\
\hline 1 & Librarian \\
\hline 1 & Geologist \\
\hline 1 & International Studies \\
\hline 1 & Historian \\
\hline 1 & Informatics Technology \\
\hline 1 & Healthcare Management \\
\hline 2 & Molecular Biology \\
\hline 2 & Physiotherapist \\
\hline 2 & Psychologist \\
\hline 3 & Political scientist \\
\hline 4 & Registered Nurse \\
\hline 4 & Pharmacist \\
\hline 5 & Public Administration \\
\hline 5 & Mathematician \\
\hline 6 & Sociologist \\
\hline 6 & Military \\
\hline 8 & Lawyer \\
\hline 9 & Engineer/Civil Engineer \\
\hline 10 & Physicist/Chemist \\
\hline 11 & Technological Education (marketing, dietetics, tourism etc.) \\
\hline 11 & Business Administration \\
\hline 11 & School Teacher \\
\hline 20 & Economist \\
\hline 23 & Doctor \\
\hline
\end{tabular}

Total: 149 
published in the Government Gazette, regarding the 120 public Greek hospitals which follow the already mentioned recruitment process. Fifty four out of 120 hospitals are interlocked in a form of 2 or 3 health units. The positions as a whole are 154, 87 of which refer to a manager's position, and 62 to that of a deputy manager. Five positions are vacant ( 3 of managers and 2 of deputy managers) and their proclamation and filling are still pending.

From the above 149 managers and deputy managers 70 possess a Master's degree and $16 \mathrm{ahD}$, while the relevance to their object is certified in 44 and 1, respectively. We must point out that 13 out of 149 had already retired before being appointed (6 military, 1 engineer, 3 school teachers, 1 economist, 2 doctors). A further research in the internet revealed the connection of the vast majority of these executives with the political party in power, mainly in the Local Self-Government. The research also revealed that $35.6 \%$ of the managers and $14.5 \%$ of the deputy managers had hands on experience, as they had been appointed in public hospitals during the same government's previous tenure.

\section{Discussion}

According to literature and findings of the above 4.2 part, the transition from Scientific to Lean Management in Greece seems a difficult one. Scientific management seeks efficiency through processes, rules, and control of the standardized work, disassembled and repeatable tasks and tightly managed procedures. However, in contemporary society organisations, the control through scientific management is a misrepresentation. Hence, the modern organisation calls for more modern management practices.

The professionalization in modern organisation theory, differs from Weber's idea of functional "specialization" of traditional occupational groups (Weber, 1964: p. 80; Meyer \& Bromley, 2013; Hindhede \& Andersen, 2019). The selection and hiring in the Japanese model take into consideration the soft skills (flexibility, teamwork, loyalty, motivation, and problem-solving capacity), education, and prior work experience (Doeringer, Evans-Klock, \& Terkla, 1998). We are also aware that the adoption of this model in other countries has demonstrated significant performances, ranging from economic efficiency to improvement and stabilization in the procedures, and especially, innovations related to quality (Lytras, 2016: pp. 107-108; Akmal, Greatbanks, \& Foote, 2020). Undoubtedly, every organisational change demands "engagement, incentivisation, and training of team leaders and members" (Hassanain, 2017; Andreasson, Ljungar, Ahlstrom, Hermansson, \& Dellve, 2018).

\section{Conclusion}

This study adds to our understanding of the possibility of adopting new highperformance management practices in Greek public hospitals, by exploring the literature and by outlining the profile of hospital managers. The target of every person, group, or authority who desires or claim to attempt the organisational 
change has to be the fulfillment of the human needs by the social organisations.

In order to accomplish the social mission of the public hospitals, it is worth investing on the principles of lean management which guarantees the efficiency and quality of the work produced, focusing on people and their needs, and as a consequence promoting the reduction of the required operational cost.

To successfully implement organisational change in the Greek public hospitals, we must nevertheless, consider that exceedance of bottlenecks is a prerequisite; exceeding the "quasi-Weberian" public administration model, the suzerainty of Taylorism, and the immured in the politicized state public sector. As long as political (party) patronage prevails and dictates, the individual interests will always outnumber the social ones, and every reformative effort will be perpetually based on unsound ground, and doomed to failure.

\section{Conflicts of Interest}

The author declares no conflicts of interest regarding the publication of this paper.

\section{References}

Akmal, A., Greatbanks, R., \& Foote, J. (2020). Lean Thinking in Healthcare-Findings from a Systematic Literature Network and Bibliometric Analysis. Health Policy, 124, 615-627. https://doi.org/10.1016/j.healthpol.2020.04.008

Aletras, V., Kontodimopoulos, N., Zagouldoudis, A., \& Niakas, D. (2007). The ShortTerm Effect on Technical and Scale Efficiency of Establishing Regional Health Systems and General Management in Greek NHS Hospitals. Health Policy, 83, 236-245. https://doi.org/10.1016/j.healthpol.2007.01.008

Alexiadis, A. (2004). The Evolution of the Management System of Hospitals in Greece. Journal of Health and Human Services Administration, 27, 331-346. http://www.jstor.org/stable/23211882

Andreasson, J., Ljungar, E., Ahlstrom, L., Hermansson, J., \& Dellve, L. (2018). Professional Bureaucracy and Health Care Managers' Planned Change Strategies: Governance in Swedish Health Care. Nordic Journal of Working Life Studies, 8, 23-41. https://doi.org/10.18291/njwls.v8i1.104849

Atkinson, J. (2017). Qualitative Methods. In J. D. Atkinson (Ed.), Journey into Social Activism: Qualitative Approaches (pp. 65-98). New York, NY: Fordham University Press. https://www.jstor.org/stable/j.ctt1hfr0rk.6

Bleich, S. A., Özaltin, E., \& Murray, J. L. C. (2009). How Does Satisfaction with the Health-Care System Relate to Patient Experience? Bulletin of the World Health Organization, 87, 271-278. https://doi.org/10.2471/BLT.07.050401

Dennis, P. (2015). Lean Production Simplified: A Plain-Language Guide to the World's Most Powerful Production System. New York, NY: CRC Press, Taylor \& Francis Group.

Diefenbach, T. (2013). Incompetent or Immoral Leadership? Why Many Managers and Change Leaders Get It Wrong. In R. T. By, \& B. Burnes (Eds.), Organizational Change, Leadership and Ethics: Leading Organizations towards Sustainability (pp. 149-170). Abingdon-on-Thames: Routledge.

Dinas, K., Vavoulidis, E., Pratilas, G. C., Basonidis, A., Liberis, A., Zepiridis, L. et al. (2019). Greek Gynecology Healthcare Professionals towards Quality Management Sys- 
tems. International Journal of Health Care Quality Assurance, 32, 164-175. https://doi.org/10.1108/IJHCQA-05-2017-0083

Doeringer, P., Evans-Klock, C., \& Terkla, D. (1998). Hybrids or Hodgepodges? Workplace Practices of Japanese and Domestic Startups in the United States. Industrial and Labor Relations Review, 51, 171-186. https://doi.org/10.1177\%2F001979399805100201

Economou, C. (2010). Greece: Health System Review. Health Systems in Transition, 12, 1-177, xv-xvi. https://pubmed.ncbi.nlm.nih.gov/21330233/

Economou, C., \& Panteli, D. (2019). Monitoring and Documenting Systemic and Health Effects of Health Reforms in Greece. Geneva: World Health Organization.

https://www.euro.who.int/en/countries/greece/publications/monitoring-and-document ing-systemic-and-health-effects-of-health-reforms-in-greece-2019

Economou, C., Kaitelidou, D., Kentikelenis, A., Maresso, A., \& Sissouras, A. (2015). The Impact of the Crisis on the Health System and Health in Greece. In A. Maresso, P. Mladovsky, Thomson, S. et al. (Eds.), Economic Crisis, Health Systems and Health in Europe: Country Experience (pp. 103-138). Copenhagen: European Observatory on Health Systems and Policies. https://www.ncbi.nlm.nih.gov/books/NBK447857/

Fiorio, C. V., Gorli, M., \& Verzillo, S. (2018). Evaluating Organizational Change in Health Care: The Patient-Centered Hospital Model. BMC Health Services Research, 18, Article No. 95. https://doi.org/10.1186/s12913-018-2877-4

Government Gazette A/32/27.3.1986. http://www.et.gr

Hall, P. (1993). Policy Paradigms, Social Learning, and the State: The Case of Economic Policymaking in Britain. Comparative Politics, 25, 275-296.

https://doi.org/10.2307/422246

Hall, P. A., \& Taylor, R. C. R. (1996). Political Science and the Three New Institutionalisms. Political Studies, 44, 936-957. https://doi.org/10.1111\%2Fj.1467-9248.1996.tb00343.x

Hassanain, M. (2017). An Overview of the Performance Improvement Initiatives by the Ministry of Health in the Kingdom of Saudi Arabia. Inquiry, 54, 1-6. https://doi.org/10.1177\%2F0046958017707872

Hindhede, A. L., \& Andersen, V. (2019). Interdisciplinary Promises and Hierarchical Ambiguities in a Danish Hospital Context. Professions and Professionalism, 9, No. 1. https://doi.org/10.7577/pp.2862

Katharaki, M. (2008). Approaching the Management of Hospital Units with an Operation Research Technique: The Case of 32 Greek Obstetric and Gynaecology Public Units. Health Policy, 85, 19-31. https://doi.org/10.1016/j.healthpol.2007.06.001

Kentikelenis, A., Karanikolos, M., Reeves, A., McKee, M., \& Stuckler, D. (2014). Greece's Health Crisis: From Austerity to Denialism. The Lancet, 383, 748-753. https://doi.org/10.1016/S0140-6736(13)62291-6

Kollberg, B., Dahlgaard, J. J., \& Brehmer, P. (2007). Measuring Lean Initiatives in Health Care Services: Issues and Findings. International Journal of Productivity and Performance Management, 56, 7-24. https://doi.org/10.1108/17410400710717064

Kotter, J. P. (1996). Leading Change (pp. 6). Boston, MA: Harvard Business Press.

Kounetas, K., \& Papathanassopoulos, F. (2013). How Efficient Are Greek Hospitals? A Case Study Using a Double Bootstrap DEA Approach. The European Journal of Health Economics, 14, 979-994. http://www.jstor.org/stable/42002304 https://doi.org/10.1371/journal.pone.0077279

Kroezen, M., van Dijk, L., Groenewegen, P. P., \& Francke, A. L. (2013). Knowledge Claims, Jurisdictional Control and Professional Status: The Case of Nurse Prescribing. PLoS 
ONE, 8, e77279. https://doi.org/10.1371/journal.pone.0077279

Ladi, S. (2014). Austerity Politics and Administrative Reform: The Eurozone Crisis and Its Impact upon Greek Public Administration. Comparative European Politics, 12, 184208. https://doi.org/10.1057/cep.2012.46

Lorenz, E., \& Valeyre, A. (2004). Organisational Change in Europe: National Models or the Diffusion of a New "One Best Way"? DRUID Summer Conference-Industrial Dynamics, Innovation and Development, Elsinore, June 14-16 2004, 1-26. https://www.researchgate.net/publication/4979970 Organisational Change in Europe National Models or the Diffusion of a New One Best Way

Lytras, A. N. (2016). Wage Labour in Modern Society. The Current Realities and the Challenge of Change. Athens: Papazissis Publishers. eBook. https://books.apple.com/us/book/wage-labour-in-modern-society/id1082681265

Manos, A., Sattler, M., \& Alukal, G. (2006). Make Healthcare Lean. Quality Progress, 39, 24-30.

Martin, B. (2016). What's Happening to Our Universities? Prometheus, 34, 7-24. https://doi.org/10.1080/08109028.2016.1222123

Meyer, J., \& Bromley, P. (2013). The Worldwide Expansion of “Organization”. Sociological Theory, 31, 366-389. https://doi.org/10.1177\%2F0735275113513264

Mintzberg, H. (1983). Power in and around Organizations. Englewood Cliffs, NJ: Prentice-Hall.

Mintzberg, H. (1997). Toward Healthier Hospitals. Health Care Management Review, 22, 9-18. https://doi.org/10.1097/00004010-199710000-00005

Natsis, C., Chrysanthopoulos, S., \& Stamouli, M. (2020). Health Professionals' Attitudes towards Digital Transformation through the Use of Hospital Information Systems: The Case of a General Oncology Hospital of Attica. Open Journal of Social Sciences, 8, 321335. https://doi.org/10.4236/jss.2020.810021

NBC (National Broadcasting Company) (1980). If Japan Can, Why Can't We? https://www.youtube.com/watch?v=vcG Pmt Ny4\&feature=emb logo

Niakas, D. (2013). Greek Economic Crisis and Health Care Reforms: Correcting the Wrong Prescription. International Journal of Health Services, 43, 597-602.

http://www.jstor.org/stable/45131881 https://doi.org/10.2190\%2FHS.43.4.a

OECD (Organisation für wirtschaftliche Zusammenarbeit und Entwicklung) (2019). “Serving Citizens Scorecards", in Government at a Glance 2019. Paris: OECD Publishing.

Parsons, T. (1951). The Social System. New York, NY: Free Press of Glencoe.

Simou, E., \& Koutsogeorgou, E. (2014). Effects of the Economic Crisis on Health and Healthcare in Greece in the Literature from 2009 to 2013: A Systematic Review. Health Policy, 115, 111-119. https://doi.org/10.1016/j.healthpol.2014.02.002

Sotiropoulos, D. A. (1995). The Remains of Authoritarianism: Bureaucracy and Civil Society in Post-Authoritarian Greece. Cahiers d'études sur la Méditerranée orientale et le monde turco-iranien, 20, 94-120. https://doi.org/10.4000/cemoti.1674

Souliotis, K., Golna, C., Tountas, Y., Siskou, O., Kaitelidou, D., \& Liaropoulos, L. (2016). Informal Payments in the Greek Health Sector Amid the Financial Crisis: Old Habits Die Last... The European Journal of Health Economics, 17, 159-170.

http://www.jstor.org/stable/24774125

https://doi.org/10.1007/s10198-015-0666-0

Taylor, F. W. (1919). The Principles of Scientific Management. New York, NY and Lon- 
don: Harper \& Brothers Publishers.

Taylor, F. W. (2003). The Early Sociology of Management and Organizations. In K. Thompson (Ed.), Scientific Management (Vol. 1). London and New York, NY: Routledge.

Thayer, F. C. (1981). An End to Hierarchy and Competition: Administration in the PostAffluent World. New York, NY: New Viewpoints.

Tsarouchas, D. (2018). Structure, Agents and Discourse in Managing Economic Crises: The Case of Greece, 2009-2017. Uluslararası Illişkiler/International Relations, 15, 9-19. https://www.jstor.org/stable/26605004

Wang, X. (2020). Research on Sichuan Province's Innovation and Entrepreneurship Policy Text Based on Content Analysis. Open Journal of Social Sciences, 8, 72-90. https://doi.org/10.4236/jss.2020.85006

Weber, M. (1964). The Theory of Social and Economic Organization (A. M. Henderson \& T. Parsons Trans.). Wilmington, IL: The Free Press.

Weber, M. (1978). Economy and Society. An Outline of Interpretive Sociology (Roth Guenther \& Wittich Claus Eds; Fischoff Ephraim, Gerth Hans, Henderson A.M., Kolegar Ferdinand, Mills C. Wright, Parsons Talcott, Rheinsterin Max, Roth Guenther, Shils Edward \& Wittich Claus Trans.). Berkeley, CA; Los Angeles, CA; London: University of California Press.

Weber, M. (2019). Economy and Society: A New Translation (T. Keith, Ed. \& Trans.). Cambridge, London: Harvard University Press. https://doi.org/10.4159/9780674240827

Whitwell, K., Maynard, R., Barry, N., Cowling, V., \& Taraet, S. (2020). Strategic Planning and Response to COVID-19 in a London Emergency Department. Emergency Medicine Journal, 37, 567-570. https://doi.org/10.1136/emermed-2020-209797 